\title{
EDITORIAL
}

\section{The remarkable Juliano Moreira (1872-1933): an Afro-Brazilian psychiatrist, scientist, and humanist in an environment of slavery and racism}

\author{
Antonio E. Nardi, ${ }^{1,2}$ (iD Mauro G. Carta, ${ }^{3}$ (iD Edward Shorter ${ }^{4}$ (DD \\ ${ }^{1}$ Laboratório Pânico e Respiração, Instituto de Psiquiatria (IPUB), Universidade Federal do Rio de Janeiro (UFRJ), Rio de Janeiro, RJ, Brazil. \\ ${ }^{2}$ Academia Brasileira de Ciências and Academia Nacional de Medicina, Brazil. ${ }^{3}$ Dipartimento di Scienze Mediche e Sanità Pubblica, Università \\ di Cagliari, Cagliari, Italy. ${ }^{4}$ Faculty of Medicine, University of Toronto, Toronto, Canada.
}

Juliano Moreira (Salvador, January 6, 1872 - Petrópolis, May 2, 1933) was a Brazilian psychiatrist who, at the beginning of the 20th century, promoted the best scientific knowledge in Brazilian psychiatry. He made unique contributions to Brazilian science and society in both his personal and professional life, and deserves recognition from those who oppose racism and fight for education as the basis of a better world. ${ }^{1,2}$

Born when slavery was still in force in Brazil, his mother, Galdina Joaquina do Amaral, was a slave at the residence of Luís Adriano Alves de Lima Gordilho, Baron de Itapuã. When Juliano was 13 years old, his mother died and he was singled out as exceptional by Manoel do Carmo Moreira Júnior, a Portuguese public lighting inspector. Thanks to the support of the Baron de Itapoã, who recognized the young man's intelligence and promise, Moreira was able to prepare for and matriculate in the Bahia School of Medicine in 1886, two years prior to the abolition of slavery. He graduated in 1891 at the age of 19 , writing his thesis on early syphilis. ${ }^{1}$ In 1896 , he competed for a substitute lecturer position in the nervous and mental illness department and was hired after receiving a perfect score. A standout in dermatology, he was the first researcher to identify cutaneous-mucous leishmaniasis and sought to prove there was no racial factor in disease. ${ }^{1,3}$

In 1903, after working in a psychiatric clinic in Bahia, he moved to Rio de Janeiro, where between 1903 and 1930 he directed the National Hospice for the Insane and, although he was not on the faculty of the Rio de Janeiro School of Medicine, he did teach psychiatry interns. His students went on to a variety of medical specialties, such as neurology, psychiatry, internal medicine and forensic psychiatry. During his tenure at the National Hospice for the Insane, he humanized treatment, ending patient confinement. ${ }^{3}$ In 1905, alongside Afrânio Peixoto and other colleagues, he founded the Arquivos Brasileiros de Psiquiatria, Neurologia e Ciências Afins (Brazilian Archives of Psychiatry, Neurology and Related Sciences). The

Correspondence: Antonio E. Nardi, Rua Visconde de Pirajá, 407/ 702, CEP 21941-901, Rio de Janeiro, RJ, Brazil.

E-mail: antonioenardi@gmail.com

Submitted May 03 2020, accepted May 05 2020, Epub Jun 122020. following year, he installed a laboratory section at the hospice, performing the first lumbar punctures and cytological exams of cerebrospinal fluid for diagnostic purposes in cases of spinal syphilis (tabes dorsalis), paralytic dementia, cerebral syphilis and various forms of meningitis. He created a judicial asylum, the first in the New World.

In sum, Moreira revolutionized psychiatric concepts and methods in Brazil, especially regarding care for people with mental disorders. ${ }^{2}$ His legacy includes the development of new psychiatric care models, including a law providing for assistance to the mentally ill, which passed on December 22, 1903. He fought scientific racism, refuting the supposition that mental illnesses are linked with skin color. ${ }^{1-3}$

Prior to Moreira, the French psychiatric model had been adopted wholesale in Brazil without regard to cultural differences. However, Moreira embraced the German model, including many of Kraepelin's ideas on classification and transcultural psychiatry, which began a theoretical renovation of Brazilian psychiatric ideas. ${ }^{4} \mathrm{He}$ set out to create a more humanistic model of care that was better adapted to the cultural characteristics of Brazil at the beginning of the 20th century. He removed the bars from the windows of the wards, abolished straitjackets, and created the Seabra Pavilion, a large building for patient vocational training in blacksmithing, firefighting, electrical mechanics, carpentry, joinery, typography and bookbinding, shoemaking, bedding and broom making, and painting. There, patients performed activities that helped in their recovery and brought them some income. Moreira began broadcasting music in the corridors as a form of therapy and turned the hospice into a cultural institution, bringing in teachers and scientists and setting up artistic workshops in anticipation of occupational therapy. For example, Albert Einstein visited Brazil in 1925 (Figure 1) and, after a speech at the Brazilian Academy of Sciences, broke protocol and accepted Moreira's invitation to the
How to cite this article: Nardi AE, Carta MG, Shorter E. The remarkable Juliano Moreira (1872-1933): an Afro-Brazilian psychiatrist, scientist, and humanist in an environment of slavery and racism. Braz J Psychiatry. 2021;43:237-239. http://dx.doi.org/10.1590/15164446-2020-1097 


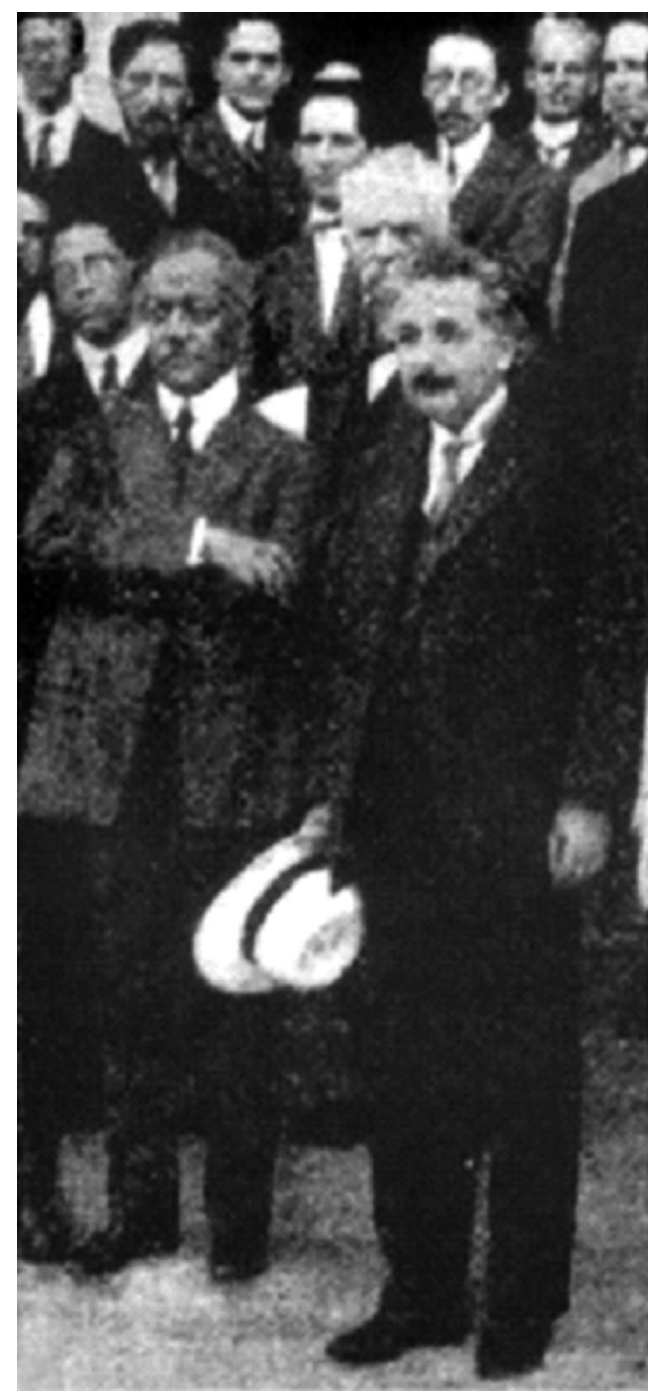

Figure 1 Juliano Moreira and Albert Einstein in 1925 in Rio de Janeiro, Brazil. Juliano Moreira was vice-president of the Brazilian Academy of Sciences, fluent in German, and an internationally recognized scientist. Photo detail from the Arquivo Memorial Juliano Moreira.

National Hospice, where he was delighted with the ongoing therapeutic workshops for psychiatric patients. ${ }^{1,5}$

Juliano Moreira was the first Brazilian psychiatrist to receive international recognition. He was fluent in French, German, Spanish, Portuguese, and English (the latter spoken with the facility of a polished upper-class Englishman) and participated in many medical congresses, representing Brazil abroad on several occasions. ${ }^{3}$ From 1895 to 1902 , he taught courses and supervised mental illness internships, visiting many psychiatric facilities in Germany, England, France, Italy and Scotland. He represented Brazil at an international congress in Paris (1904) and was elected Honorary President of the 4th International Congress on Assistance to the Insane. He was also a Brazilian delegate to congresses in Lisbon (1906), Milan (1907), Amsterdam (1907), London (1913), and Brussels (1913).
While abroad, he was also obliged to seek out specialists and clinics for his tuberculosis. At a sanatorium in Cairo, he met Augusta Peick, a German nurse from Hamburg. The two got married in the early 1910s and returned to Brazil together. ${ }^{6}$

Moreira was elected a full member of the National Academy of Medicine in Brazil in 1903 (the patron of chair 57). He was one of the founders of the Brazilian Academy of Sciences and was its president from 1926 to 1929. Due to his ethical and moral views, his tireless work and multidisciplinarity, he was elected to a number of organizations, including the Medico-Legal Society of New York, the Sociedad de Neurología y Psiquiatria de Buenos Aires, the Anthropologische Gesellschaft of Munich; the Société de Médicine de Paris, the Société de Pathologie Exotique, the Sociéte Clinique de France, the Société Clinique de Medicine Mentale, the National Defense League, the Mental Hygiene League, the American Academy of Political and Social Science, the Société Medico Psychologique de Paris, the Instituto Histórico e Geográfico Brasileiro, the Academia de Letras da Bahia, and the Instituto Brasileiro de Ciências. ${ }^{3}$ In July 1928, he began a long journey to the Far East, including stops at Tokyo, Kyoto, Sendai, Hokkaido, Osaka and Funoko, ${ }^{7}$ receiving the Order of the Sacred Treasure from the Emperor of Japan as a "contributor to world science." This was due in part to his struggle against prejudice and discrimination, which was also being directed at SinoJapanese immigrants to Brazil, who were referred to as the "Perigo Amarelo" (Yellow Peril).

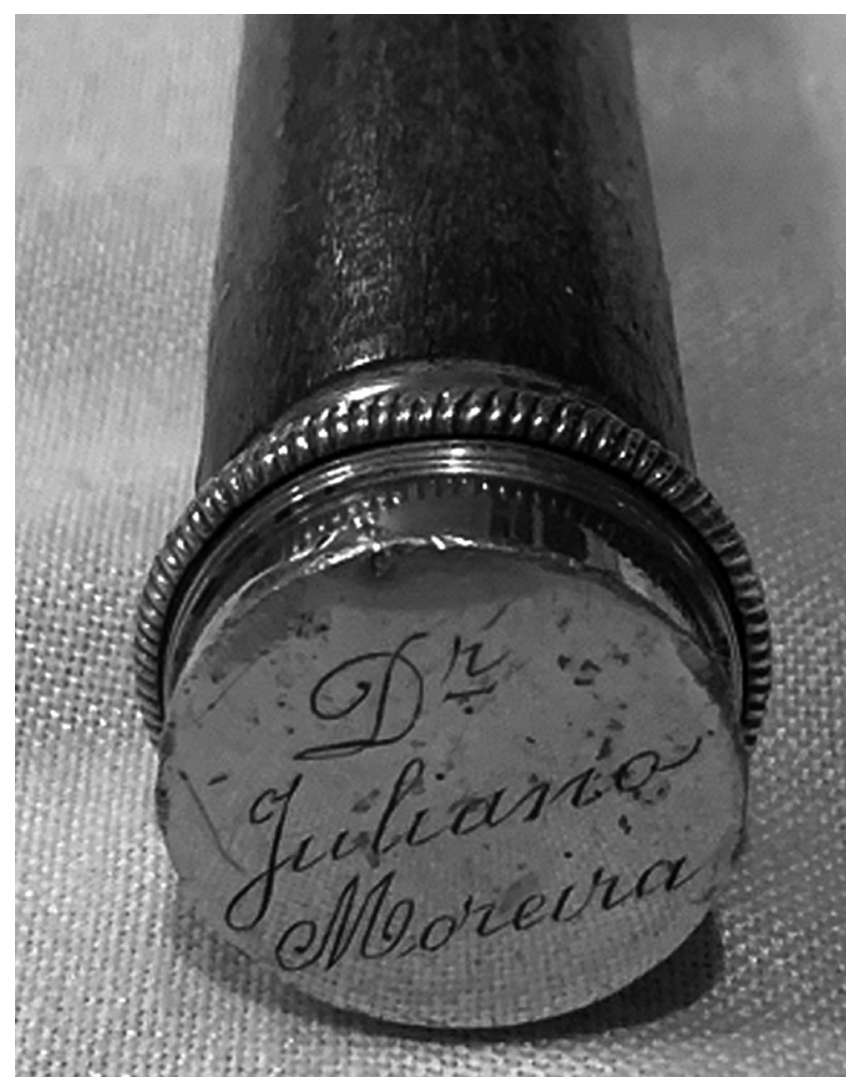

Figure 2 Detail of Juliano Moreira's cane.Private collection. 
Juliano Moreira defended the idea that mental illness originated from physical and situational factors, such as poor hygiene and lack of access to education. This contradicted the racist thinking currently in vogue in national academia, which attributed psychological problems in Brazil to miscegenation. ${ }^{5}$ One important aspect of his work was combatting the idea that racial miscegenation was leading to the degeneration of the Brazilian population. He argued that mental illness was caused by factors such as alcoholism, syphilis, parasites and adverse health and educational conditions. In addition to broadening the scope of Brazilian psychiatry, he initiated a new approach to the treatment of mental illness. ${ }^{5}$

The life of this outstanding psychiatrist, scientist and humanist has been described in numerous publications, ${ }^{5}$ and his career was far greater than this brief summary can recount. He died on May 2, 1933, at the Correias Sanatorium in Petrópolis, where he was admitted for tuberculosis treatment (Figure 2). He left no children.

\section{Acknowledgements}

The authors are grateful to Prof. Jayme Brandão de Marsillac for his support in carrying out this editorial.

\section{Disclosure}

The author reports no conflicts of interest.

\section{References}

1 Lyrio A. Juliano Moreira. O terapeuta do afeto. Salvador: Assembleia Legislativa da Bahia; 2012.

2 Oda AM, Piccinini W, Dalgalarrondo P. Juliano Moreira (1873-1933): founder of scientific psychiatry in Brazil. Am J Psychiatry. 2005;162: 666.

3 Venancio AT. As faces de Juliano Moreira: luzes e sombras sobre seu acervo pessoal e suas publicações. Rev Estud Hist. 2005;2: 59-73.

4 Dalgalarrondo P. Cartas de Juliano Moreira a Emil Kraepelin. In: Dalgalarrondo P. Civilização e loucura: uma introdução à história da etnopsiquiatria. São Paulo: Lemos; 1996. p. 117-24.

5 Oda AM, Dalgalarrondo P. Juliano Moreira: um psiquiatra negro frente ao racismo científico. Braz J Psychiatry. 2000;22:178-9.

6 Litaiff H. Carta do Egito. Contribuição para a história da psiquiatria no Brasil. Rio de Janeiro: Schulze; 1982.

7 Moreira J. Impressões de uma viagem ao Japão em 1928. Rio de Janeiro: Reginaldo Neustadt; 1935. 